\title{
Distinct functions of dynamin isoforms in tumorigenesis and their potential as therapeutic targets in cancer
}

\author{
Jianghui Meng ${ }^{1,2}$ \\ ${ }^{1}$ Charles Institute of Dermatology, School of Medicine and Medical Sciences, University College Dublin, Belfield, Dublin, \\ Ireland \\ 2 International Centre for Neurotherapeutics, Dublin City University, Glasnevin, Dublin, Ireland \\ Correspondence to: Jianghui Meng, email: jianghui.meng@ucd.ie \\ email: jianghui.meng@dcu.ie
}

Keywords: endocytosis, tumor, cancer target, clathrin, amphiphysin

Received: September 28, $2016 \quad$ Accepted: March 09, $2017 \quad$ Published: March 29, 2017

Copyright: Meng et al. This is an open-access article distributed under the terms of the Creative Commons Attribution License 3.0 (CC BY 3.0), which permits unrestricted use, distribution, and reproduction in any medium, provided the original author and source are credited.

\section{ABSTRACT}

Dynamins and their related proteins participate in the regulation of neurotransmission, antigen presentation, receptor internalization, growth factor signalling, nutrient uptake, and pathogen infection. Recently, emerging findings have shown dynamin proteins can also contribute to the genesis of cancer. This up-todate review herein focuses on the functionality of dynamin in cancer development. Dynamin 1 and 2 both enhance cancer cell proliferation, tumor invasion and metastasis, whereas dynamin 3 has tumor suppression role. Antisense RNAs encoded on the DNA strand opposite a dynamin gene regulate the function of dynamin, and manipulate oncogenes and tumor suppressor genes. Certain dynamin-related proteins are also upregulated in distinct cancer conditions, resulting in apoptotic resistance, cell migration and poor prognosis. Altogether, dynamins are potential biomarkers as well as representing promising novel therapeutic targets for cancer treatment. This study also summarizes the current available dynamin-targeted therapeutics and suggests the potential strategy based on signalling pathways involved, providing important information to aid the future development of novel cancer therapeutics by targeting these dynamin family members.

\section{INTRODUCTION}

Cancer is associated with features of dysregulated cell proliferation and increased migration of tumor cells, resulting in aggressive cell invasion and metastatic disorders. Dysregulation of endocytosis in cancer cells alters cell surface expression of critical molecules, leading to the dysfunction of cell signaling, migration, survival and proliferation. Endocytosis is critical for maintaining neurotransmission, antigen presentation, receptor internalization, growth factors signalling, nutrient uptake, and pathogen infection. In many cell types, multiple endocytotic pathways exist which differ in the proteins utilised and molecules endocytosed [1]. Dynamins support endocytosis by either clathrin-dependent or -independent mechanisms $[1,2]$. In the case of receptor-mediated endocytosis, dynamins, clathrin, clathrin adaptor proteins (i.e. adaptor protein complex) as well as amphiphysins are essential. During endocytosis, receptor binding is mediated by clathrin adaptors that can bind directly to both clathrin and the lipid and/or protein components of membranes. Clathrin forms a triskelion shape composed of three clathrin heavy chains and three light chains, which is the assembly unit of a clathrin coated pit [3]. Not all the endocytosis requires clathrin, for example, in quiescent nerve endings a slow endocytosis can occur independent of dynamin and clathrin, however, in an intense stimulation condition, a fast endocytosis can occur as stimulation recruits dynamin, clathrin, clathrin adaptor protein 2 (AP2) complex, and amphiphysin to increase protein internalization (Figure 1). Moreover, numerous studies have shown that dynamin-independent and -dependent membrane recycling are independent processes linked to spontaneous and evoked exocytosis, 
respectively [4].

\section{THERAPEUTIC POTENTIAL OF DYNAMIN ISOFORMS}

Dynamins are large GTPase, encoded by three genes in mammals, required for vesicle recycling and membrane fission. Dynamins can be directed by amphiphysins to sites of endocytosis $[5,6]$, where they form a helix around the neck of the invaginated coated pit. They can self-assemble to form ring or helix-like structures around the neck of the vesicle and play an essential role in scission of the
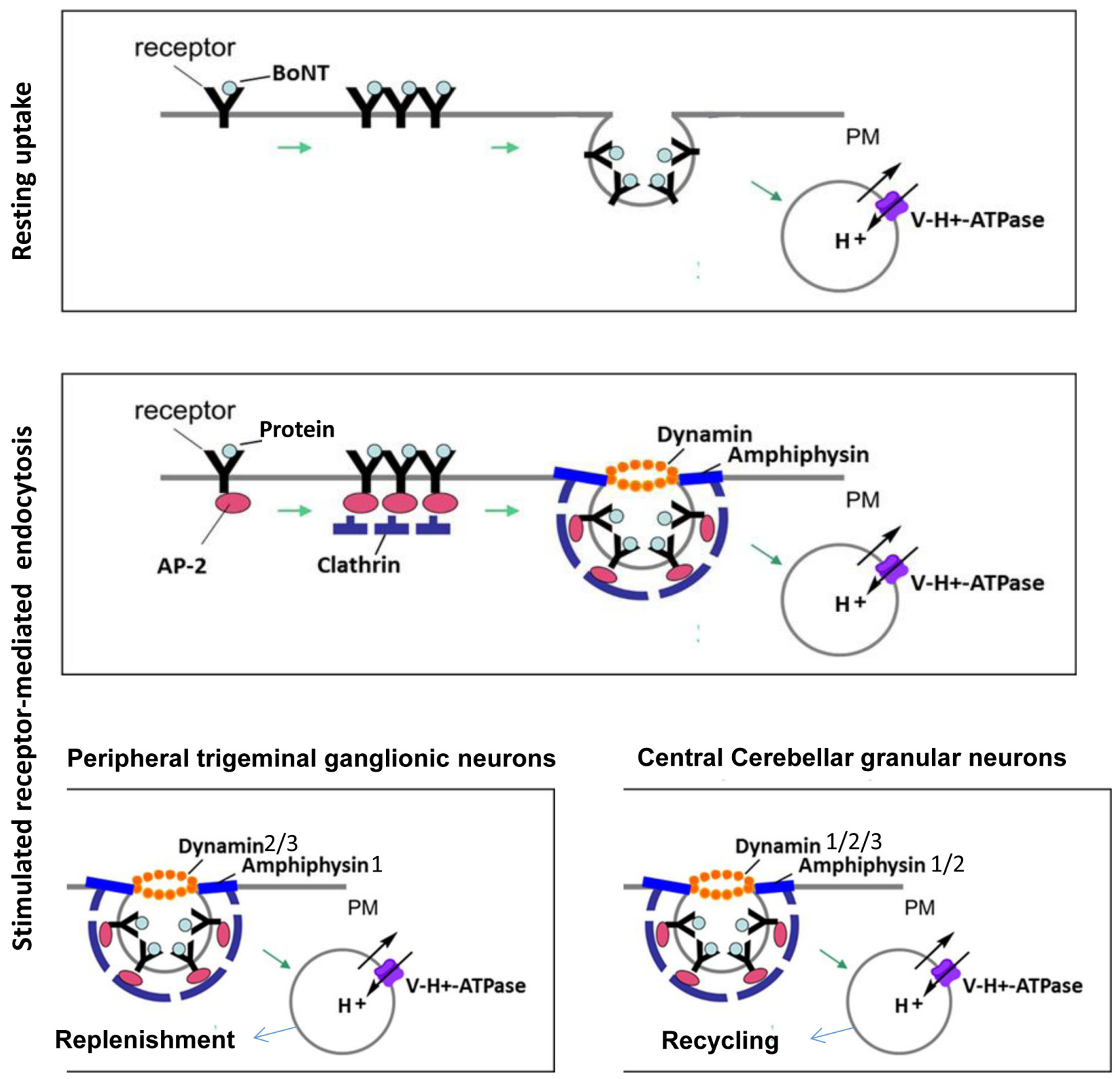

Figure 1: Schematic diagram for resting and stimulated receptor-mediated endocytosis in neurons and differential involvement of dynamin isoforms in stimulated receptor-mediated endocytosis. Using a molecular probe, such as botulinum neurotoxin (BoNT) which cleaves SNARE proteins, to dissect the path of receptor-mediated endocytosis [115], it was revealed that resting uptake by neurons occurs via lipid rafts, acidified compartments and protein acceptors but not dynamin. In contrast, stimulated endocytosis of BoNT by neurons utilises lipid rafts, acidified compartments (Vacuolar-type H+-ATPase) and dynamin and amphiphysin [4]. In terms of fast recycling of small clear synaptic vesicles, cerebellar granule neurons (CGNs) use predominantly dynamin 1, whereas isoform 2 and, to a lesser extent, isoform 3 to support a less rapid mode of stimulated endocytosis. In contrast, large dense-cored vesicle (LDCV)-releasing trigeminal ganglionic neurons (TGNs) preferentially employ dynamins 2 and 3 and amphiphysin 1 for evoked endocytosis. PM = plasma membrane, $\mathrm{V}-\mathrm{H}+=$ Vacuolar-type $\mathrm{H}+, \mathrm{CCP}=$ clathrin coated pit, $\mathrm{CME}=$ clathrin mediated endocytosis. 
Table 1: Influence of dynamin and related proteins on cancergenesis

\begin{tabular}{|c|c|c|c|}
\hline $\begin{array}{l}\text { Dynamin } \\
\text { isoforms }\end{array}$ & $\begin{array}{|lrr|}\text { Cancer cell } & \text { types } & \text { with } \\
\text { abnormally } & \text { expressed } & \text { or } \\
\text { activated dynamin proteins } & \end{array}$ & Outcome & \\
\hline Dynamin 1 & $\begin{array}{l}\text { Acute myeloid leukemia, lung and } \\
\text { colon adenocarcinomas, } \\
\text { H1299 non-small lung cancer cells }\end{array}$ & $\begin{array}{l}\text { Aberrant trafficking of nascent clathrin-coated vesicles } \\
\text { and alteration of cell signalling and enhancement of cell } \\
\text { proliferation; dynamin } 1 \text { is acutely activated by an Akt/ } \\
\text { GSK3 } \beta \text { signalling cascade to increase the rate of CCP } \\
\text { initiation in the H1299 cancer cells. }\end{array}$ & {$[7,8,30]$} \\
\hline Dynamin 2 & $\begin{array}{l}\text { Progressive prostate cancer (PCA), } \\
\text { pancreatic tumor cells, } \\
\text { hepatocellular carcinoma (HCC) } \\
\text {, colon-derived tumor cell line, } \\
\text { HCT116, pancreatic tumor cells, } \\
\text { malignant glioblastomas, } \\
\text { breast-cancer cells, human non- } \\
\text { small cell lung carcinoma cells, } \\
\text { invasive bladder cancer cells, } \\
\text { adult T-cell acute lymphoblastic } \\
\text { leukemia }\end{array}$ & $\begin{array}{l}\text { Dynamin } 2 \text { expression is significantly increased in } \\
\text { these cancer conditions. Dynamin } 2 \text { is involved in } \\
\text { the promotion of cytokinesis, enhancement of tumor } \\
\text { invasion and metastasis. Dynamin } 2 \text { overexpression is } \\
\text { associated with poor prognosis; Dynamin } 2 \text { and cortactin } \\
\text { participate in cell migration by stabilizing F-actin bundles } \\
\text { in filopodia. Dynamin } 2 \text { contributes to the bladder cancer } \\
\text { invasion by controlling invadopodia formation; Mutation } \\
\text { of dynamin } 2 \text { in oncogenesis of T-cell acute lymphoblastic } \\
\text { leukemia }\end{array}$ & $\begin{array}{l}{[33,37} \\
39,42,45 \\
99-103]\end{array}$ \\
\hline Dynamin 3 & $\begin{array}{l}\text { Hepatocellular } \quad \text { carcinoma } \\
\text { pathogenesisis }\end{array}$ & $\begin{array}{l}\text { Dynamin } 3 \text { gene (DNM3) is hyper-methylated and } \\
\text { protein expression level is decreased. Dynamin } 3 \text { has } \\
\text { tumor suppressive function in HCC by upregulating and } \\
\text { activating p53. }\end{array}$ & {$[46,47]$} \\
\hline $\begin{array}{l}\text { Dynamin- } \\
\text { related protein } 1\end{array}$ & $\begin{array}{l}\text { Lung and breast cancers, } \\
\text { glioblastoma cells, } \\
\text { Human lung cancer cell; T-cell } \\
\text { acute lymphoblastic leukemia cells }\end{array}$ & $\begin{array}{l}\text { Drp1 is upregulated in certain types of cancers. } \\
\text { Upregulated Drp } 1 \text { confers chemotherapy resistance, } \\
\text { induces apoptotic resistance and autophagy, facilities cell } \\
\text { cycle progression, generates genome instability, promotes } \\
\text { cell migration and induces poor prognosis. }\end{array}$ & $\begin{array}{l}{[26,67,} \\
69,70]\end{array}$ \\
\hline $\begin{array}{l}\text { Mitofusin } 1 \text { and } \\
\text { Mitofusin } 2\end{array}$ & $\begin{array}{l}\text { Human lung cancer cells } \\
\text { express imbalance of Drp 1/ } \\
\text { Mfn } 2 \text { expression (an increase } \\
\text { in Drp-1 and decrease in Mfn- } \\
2 \text { ); downregulation of Mfn2 in } \\
\text { hepatocellular carcinoma cells }\end{array}$ & $\begin{array}{l}\text { Mfn-1 and }-2 \text { induce mitochondrial fission. } \\
\text { Overexpression of Mfn-2, Drp-1 inhibition, or Drp- } 1 \\
\text { knockdown results in a marked reduction of cancer cell } \\
\text { proliferation and an increase in spontaneous apoptosis. }\end{array}$ & $\begin{array}{l}{[23, \quad 25-} \\
27,104]\end{array}$ \\
\hline $\begin{array}{l}\text { Dynamin-like } \\
\text { GTPase optic } \\
\text { atrophy } 1\end{array}$ & $\begin{array}{l}\text { Lung adenocarcinoma cells and } \\
\text { hepatocellular carcinoma }\end{array}$ & $\begin{array}{l}\text { Opa1 is upregulated in various forms of cancer. cell cycle } \\
\text { progression, genome instability, cell migration, poor } \\
\text { prognosis }\end{array}$ & $\begin{array}{l}{[25} \\
75]\end{array}$ \\
\hline
\end{tabular}

invaginated vesicles during membrane fission (Figure 1). Three conventional mammalian dynamin genes (DNM1, DNM2 and DNM3) encode proteins that are $\sim 80 \%$ homologous [4]. Dynamin 1 is generally considered to be neuron specific, but a recent finding showed it can be activated to mediate rapid compensatory clathrinmediated endocytosis (CME) in non-neuronal cells [7, 8]. In contrast, dynamin 2 is ubiquitously expressed and 3 is mainly expressed in the testis, brain and low levels in the lung [9]. Despite sharing significant sequence identity, dynamin 1 and 2 differ in their curvaturegenerating/sensing properties [10]. In the peripheral sensory neurons, dynamin 1 and 2 have been found to have distinct localization, with isoform 1 located in the peri-nuclear region and 2 mainly resides on the plasmalemma, suggestive of the distinct functions for these two isoforms (Figure 2A). Dynamin 1 has more potent curvature-generating properties, and it is better suited for rapid, compensatory endocytosis at the synapse, whereas the curvature-sensing properties of dynamin 2 require a narrow neck to trigger its assembly, therefore, dynamin 2 is more suited to monitor and regulate maturation of the early stages of clathrin-coated pits (CCPs) [10]. There has been reported evidence for isoform-specific functions of dynamin 1 and 2 as well as 3 in clathrin-mediated endocytosis both at the central synapse [11], peripheral nerves [4] and non-neuronal cells [12], respectively (Figure 1). Moreover, an overlapping but distinct role between 3 isoforms of dynamin has been shown, for example, expressing any of the three dynamin isoforms in dynamin 1 knock-out (KO) neurons could compensate for the dynamin 1 phenotype [13].

Although the basis for isoform differences and their functional significance remains poorly understood, each isoform has been linked to different disease conditions, including Alzheimer's disease, Parkinson's disease, Huntington's disease, Charcot-Marie-Tooth disease, heart failure, schizophrenic, epilepsy dominant optic atrophy, 
osteoporosis, Down's syndrome and various types of cancer [14] (Table 1).

Apart from the above isoforms, dynamin-related family members also contribute to carcinogenesis or tumor suppression. These dynamin-related proteins include fission proteins, for example, the large self-assembling GTPase dynamins, related protein 1 (Drp1, also called DLP1) [15], mitochondrial fission 1 (Fis1) [16], fusion proteins (Mfn1, Mfn2) [17-20], and Optic Atrophy 1 (OPA1) [21-24]. These proteins are essential to maintain mitochondrial fission and fusion balance to provide necessary adenosine triphosphate (ATP) to neurons. It is notable that certain cancer patients revealed an imbalanced expression of dynamin-related proteins in fusion and fission which resulted in increased mitochondrial fragmentation. In particular, reduced protein expression levels of Mfn1, Mfn2, and Opa1 and high levels of Fis1 and DLP1/ Drp1 were observed in certain cancer conditions [23, 25-28] (Table 1).

\section{Dynamin 1 signalling in carcinogenesis}

Dynamin 1 has been linked to many neurological diseases for example amyotrophic lateral sclerosis and Alzheimer's disease [29]. Expression of dynamin 1 is upregulated in a number of cancer cells from acute myeloid leukaemia, lung and colon adenocarcinomas [30], perhaps reflecting a protective function against pathways of apoptosis (Table 1). It has been shown most recently that overexpression and activation of dynamin-1 is selectively activated down-stream of tumor necrosis factor (TNF)-related apoptosis-inducing ligand (TRAIL)-death receptors to self-regulate their endocytosis, attenuate apoptotic signalling, enhance cells survival and migration [8]. In another word, a reduced level of dynamin-1 expression confers greater sensitivity to TRAIL-induced apoptosis, whereas enhanced level of dynamin-1 expression results more resistance to apoptosis. Dynamin 1 is also acutely activated by Akt/GSK3 $\beta$

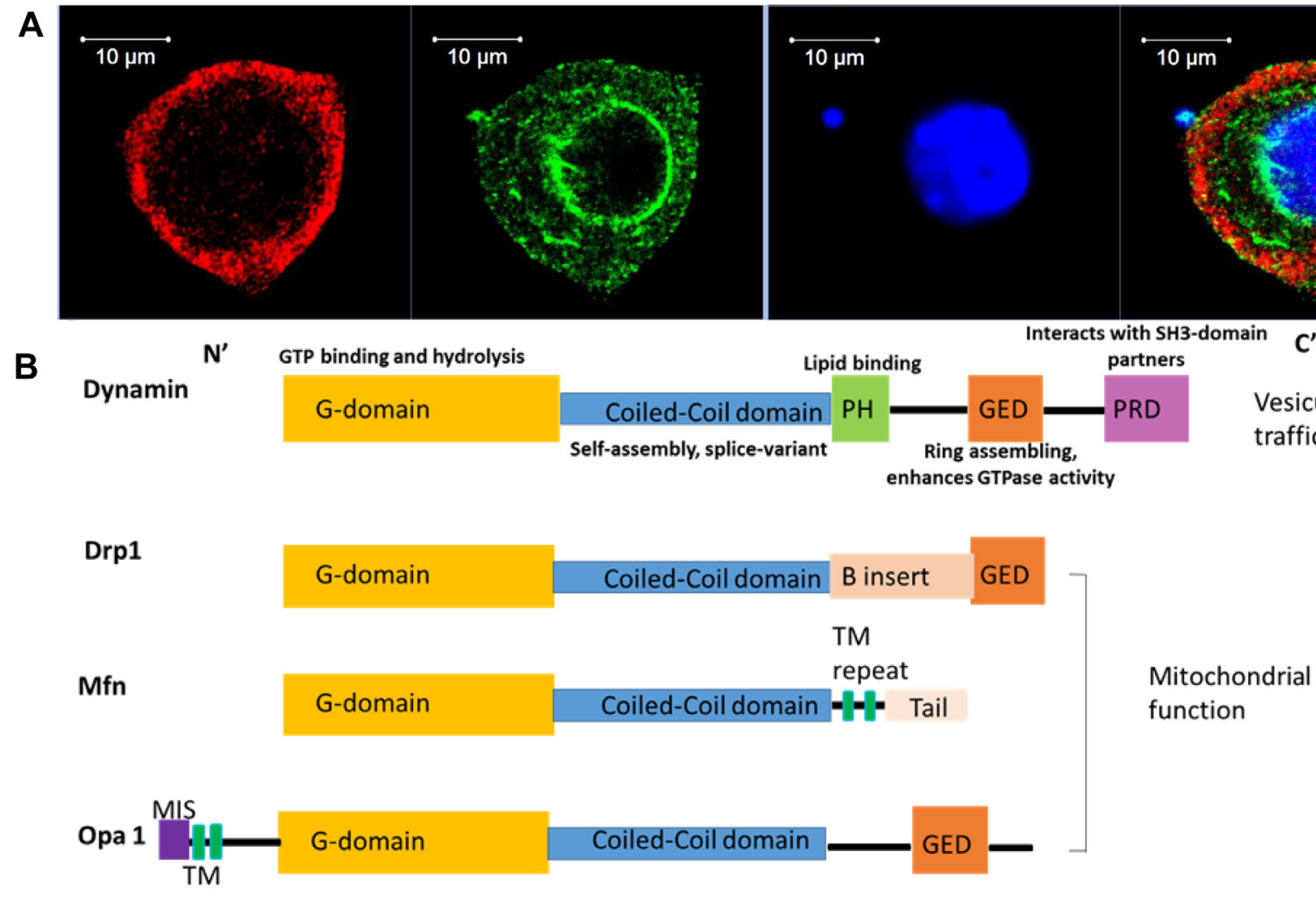

Figure 2: Distinct localization of dynamin isoforms in the peripheral neurons highlights their distinct functional importance. The linear domain arrangement of human dynamin and related proteins. A. Immuno-fluorescence study demonstrated that dynamin 1 and 2 showed distinct distribution pattern in the cultured trigeminal ganglionic neuron. Dynamin 1, green; dynamin 2, red; nuclei, blue. B. Each domain of dynamin protein is indicated as follows: G domain, yellow, is responsible for GTP binding and hydrolysis; middle coiled-coil domain- GTPase Effector Domain (GED) stalk, blue, is responsible for dynamin protein self-assembly, and variant splicing; PH domain (pleckstrin homology), green, is responsible for lipid binding; GED, orange, is responsible for ring assembling and also enhance GTPase activity; PRD (proline rich domain), light purple, interacts with SH3-domain partners, such as amphyphisin; N-terminal MIS (mitochondrial import sequence): dark purple, is responsible for targeting the OPA1 protein; B insert domain (pink) of the Dnm1 guanosine triphosphatase (a Drp) contains a novel motif required for association with the mitochondrial adaptor Mdv1 to the mitochondria. 
signalling in H1299 non-small lung cancer cells, which results in an increase of the rate of CCP initiation, and alteration of CCP dynamics, as well as triggering rapid, accelerated calthrin-mediated endocytosis (CME) [7]. The dysregulated CME leads to aberrant trafficking of nascent clathrin-coated vesicles (CCVs), and alters cell signalling and enhances cell proliferation. This function is also the first evidence of dynamin 1 function in nonneuronal cells [7]. Altogether, dynamin 1- targeted anticancer therapeutics may potentially to induce cancer cell apoptosis.

\section{Dynamin 2 as a prognostic marker in cancer}

Unlike dynamin 1, dynamin 2 has been found to be expressed ubiquitously. It is best known for its role in membrane trafficking processes and, recently, it has been uncovered to promote the cytokinesis, cell proliferation, migration, and act as prognostic marker. Dynamin 2 is required for the abscission phase of cytokinesis. Knockdown of dynamin results in multinucleation, a characteristic of a failed cytokinesis in Hela cells [31]. In terms of endocytosis, it is well known that the endocytosis of epidermal growth factor receptor (EGFR) requires dynamin 2. EGFR induces tumorigenesis by multiple signalling pathways. Amplification of both dynamin 2 and EGFR genes have been demonstrated to occur in carcinoma patients [32]. After dynamin 2 is knocked down or inhibited, the internalization of EGFR is delayed and reduced, resulting in increased EGF-mediated tumor cell migration, colony formation and invasion [33, 34]. Moreover, dynamin 2 is necessary for the endocytosis of several proteins associated with cancer motility and invasiveness, including integrin $\beta-1$ and focal adhesion (FA) kinase $[35,36]$. Knockdown dynamin 2 leads to impaired focal adhesion disassembly and cell migration. Dynamin 2 also regulates polyamine internalization in a colon-derived tumor cell line, HCT116 [37]. Polyamines are ubiquitous small basic molecules involved in primordial stress resistance and their uptake is increased in cancer cells [38]. Polyamine uptake process is independent of clathrin but it is dependent on caveolin-1, highlighting dynamin 2 regulates clathrin-independent endocytosis in cancer cells.

Dynamin 2 expression was found to be upregulated in several cancerous conditions. Its overexpression is closely associated with neoplastic prostate epithelium and its poor prognosis [39]. In isolated progressive prostate

\section{Tumor promotion}

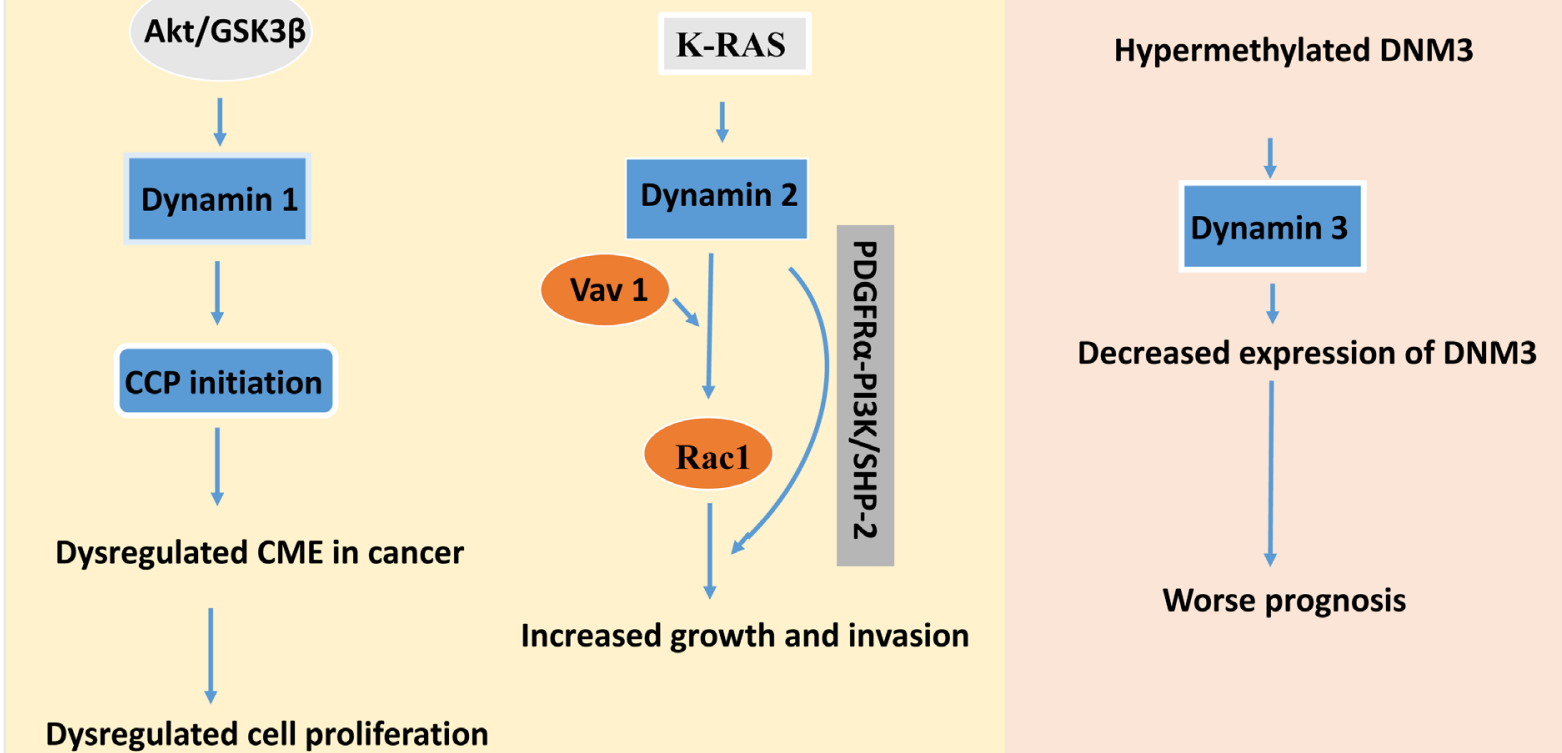

Figure 3: Schematic map for potential targets in dynamin-mediated tumor development whereas dynamin 1 and 2 act as the tumor promotors. In contrast, dynamin 3 has tumor suppressive role. Inhibition or depletion of the Akt/GSK3 $\beta$ signalling pathway will prevent the function of dynamin 1 in lung cancer cells. Moreover, inhibition of dynamin 2 interaction with Vav1 will stop the activation of Rac1, and a method that prevents phosphorylation of PDGFR $\alpha$-PI3K/SHP-2 will reduce the increased tumor growth and cancer cell invasion in certain types of cancer. Blockage of hypermethylation of DNM3 by some genetic approach or increase of expression of dynamin 3 protein will prevent the tumor development. 
Table 2: Commonly used dynamin inhibitors are not isoform specific for cancer treatment

\begin{tabular}{|c|c|c|c|}
\hline Inhibitors & Molecular formula & Targets & Function \\
\hline MiTMAB & $\mathrm{C} 17 \mathrm{H} 38 \mathrm{BrN}$ & $\begin{array}{l}\text { Dynamins1 } \\
\text { and 2 }\end{array}$ & $\begin{array}{l}\text { Surface-active, small molecule, dynamin inhibitors that block } \\
\text { endocytosis. targets the dynamin-phospholipid interaction to } \\
\text { block dynamin recruitment to membranes but not dynamin } \\
\text { oligomerization [79] }\end{array}$ \\
\hline OcTMAB & $\mathrm{C} 21 \mathrm{H} 46 \mathrm{BrN}$ & $\begin{array}{l}\text { Dynamins } 1 \\
\text { and } 2\end{array}$ & $\begin{array}{l}\text { Works together with MiTMAB to induce cytokinesis failure and } \\
\text { inhibit cell proliferation [105] }\end{array}$ \\
\hline Dynole $34-2$ & $\mathrm{C} 25 \mathrm{H} 36 \mathrm{~N} 4 \mathrm{O}$ & $\begin{array}{l}\text { Dynamins1 } \\
\text { and } 2\end{array}$ & $\begin{array}{l}\text { More efficacious and has less off-target effects than MiTMABs } \\
\text { [81]. It acts on the dynamin } G \text { domain [106]. It is not GTP } \\
\text { competitive [106]. Inhibit the activity of dynamin following } \\
\text { recruitment of dynamin to plasma membranes [83] }\end{array}$ \\
\hline Dynasore & $\mathrm{C} 18 \mathrm{H} 14 \mathrm{~N} 2 \mathrm{O} 4$ & $\begin{array}{l}\text { Dynamins } 1 \\
\text { and } 2\end{array}$ & $\begin{array}{l}\text { Noncompetitive inhibitor which dose-dependently inhibits the } \\
\text { GTPase activity of dynamin } 1,2 \text {, and Drp1 (mitochondrial) }[4 \text {, } \\
107-109]\end{array}$ \\
\hline Dyngo & C18H14N2O5 & $\begin{array}{l}\text { Dynamins } 1 \\
\text { and } 2\end{array}$ & $\begin{array}{l}\text { Greatly improved dynasore analogues, with greatly reduced non- } \\
\text { specific in vitro binding and improved potency [78]; it is more } \\
\text { potent than dynasore and more specific to block dynamin function } \\
\text { after its recruitment, with more versatile cell biology tools with } \\
\text { reduced cytotoxicity }[4,78]\end{array}$ \\
\hline Mdivi1 & $\mathrm{C} 15 \mathrm{H} 10 \mathrm{Cl} 2 \mathrm{~N} 2 \mathrm{O} 2 \mathrm{~S}$ & Drp1 & $\begin{array}{l}\text { A selective cell-permeable inhibitor of mitochondrial division by } \\
\text { blocking dynamin GTPase activity [110-113] }\end{array}$ \\
\hline Iminodyn-22 & $\mathrm{C} 23 \mathrm{H} 20 \mathrm{~N} 4 \mathrm{O} 8$ & $\begin{array}{l}\text { Dynamins } 1 \\
\text { and } 2\end{array}$ & $\begin{array}{l}\text { Binds to the GTPase domain at an allosteric site and displays } \\
\text { uncompetitive antagonism with respect to GTP }[114]\end{array}$ \\
\hline RTIL-13 & $\mathrm{C} 30 \mathrm{H} 55 \mathrm{BrN} 2 \mathrm{O} 3$ & $\begin{array}{l}\text { Dynamins } 1 \\
\text { and } 2\end{array}$ & $\begin{array}{l}\text { Inhibits dynamin I and II GTPase and targets pleckstrin homology } \\
\text { (PH) (lipid binding) domain [78] }\end{array}$ \\
\hline
\end{tabular}

cancer (PCA) cells, dynamin 2 was found to regulate focal adhesion turnover, which is critical for cell migration [39]. Elevated dynamin 2 expression levels are associated with Gleason score, tumor volume, and PCA-specific mortality. Knockdown of dynamin 2 expression or inhibition of dynamin 2 prevents cell invasiveness in androgenresponsive and -refractory PCA models, supporting the potential benefit of dynamin 2 to serve as a target for development of novel therapeutics for treatment of advanced PCA [39]. In preclinical models, dynamin 2 gene silencing significantly reduced cell migration and invasion in vitro, as well as tumor size and lymph node metastases in vivo [39]. Level of dynamin 2 was also found to be increased in the cervical cancer, which might be related to the increased proliferation, dysfunction of apoptotic activity and increased migration [40]. Together these results suggest that both enzymatic activity and proper localization of dynamin 2 are required for extracellular matrix degradation by invasive cancer cells [41].

Different cell factors are demonstrated to be 
involved in the regulation of dynamin 2 function, for example, dynamin 2 is regulated by proto-oncogenic expression of K-RAS in human colon cancer cells [37] and promotes pancreatic cancer cell migration through activation of Rac1 [42]. Dynamin 2 has been identified as a Vav1-SH3 interacting protein which remodels actin in T cells [43] and this interaction is deemed specific to Vac1, rather than Vac2 or 3 (Figure 3). Vac1 also interacts with an actin regulatory scaffold protein Zyxin which is known to be involved in cell adhesion, cell migration and integrin function in $\mathrm{T}$ cells and control the cancer cell motility through integrin [44]. More recently, in pancreatic tumor cells, dynamin 2 was found to promote lamellipodia formation and pancreatic tumor cell migration by its direct binding with Vav1 to promote Rac1 activation and migration [42].

In brain cancer, dynamin 2 is a downstream effector of the PDGFR $\alpha$-PI3K/SHP-2 signalling in glioma cells and mediates PDGFR $\alpha$-SHP-2-promoted glioblastoma growth and invasion [45]. Depletion of endogenous dynamin 2 by short hairpin RNAs (shRNAs) inhibited PDGFR $\alpha$-stimulated phosphorylation and activation of Akt, extracellular signal-regulated kinase 1/2, Rac1 and Cdc42, prevented glioma cell migration and tumor growth as well as invasion in the brains of mice. Thus, targeting dynamin 2 or PDGFR $\alpha$-SHP-2-Dynamin 2 pathway may be beneficial to patients with malignant glioblastomas [45].

\section{Dynamin 3 as a tumor suppressor}

Differing from dynamin 1 and 2, dynamin 3 can function as a suppressor of tumorigenesis by induction of p53 expression and activation [46]. Interestingly, dynamin 3 gene (DNM3) was identified as one of the genes associated with hepatocellular carcinoma pathogenesisis, from a triple combination array carried out in surgical specimens obtained from hepatocellular carcinoma (HCC) patients. $48 \mathrm{HCC}$ patients were evaluated in that study for DNM3 methylation and expression status using methylation specific polymerase chain reaction (MSP-PCR) and semi-quantitative reverse transcriptase RT-PCR, respectively [47]. DNM3 was found being hypermethylated in cancer tissue compared with adjacent normal tissue, and this was associated with decreased expression of DNM3 in cancerous tissue (Figure 3). Patients with reduced expression of dynamin 3 in tumor tissues exhibited worse prognosis with decreased disease specific survival compared to patients without decreased expression [47].

\section{DYNAMIN GENE-RELATED NON-CODING RNAS ARE BIFUNCTIONAL}

Non-coding RNAs are found to have a key function in the regulation of gene expression at the posttranscriptional level by base pairing with complementary regions mainly within the 3' untranslated regions (3'-UTR) of target mRNAs, thus promoting mRNA degradation and translational repression. These intronic MicroRNAs (MirRNAs) can support the function of its host gene by silencing genes that are functionally antagonistic to the host, or act synergistically with the host by coordinating the expression of genes with related functions. MirRNAs promote or inhibit cancer growth by regulate the expression of target genes. In relation to the dynamin genes, MicroRNA-214 (MiR-214) is located about $6 \mathrm{~kb}$ apart on chromosome lg24.2 in an intron of the DNM3 gene, and is also involved in carcinogenesis. Although the biological function of MiR-214 still remains unclear in certain cancers, MiR-214's pleiotropic and tumor-specific contribution to various cancer hallmarks formation and progression is achieved via several target genes [48]. It functions as both a tumor suppressor and oncogene in various types of human cancers. Moreover, MiR-214 is a novel biomarker for lymph node metastasis in patients with gastric cancer and plays an important role in the development of gastric cancer in the Chinese Han population [49]. In samples from breast cancer that resistant to cisplatin and tongue squamous carcinoma cell lines as well as in ovarian cancer resistant to platinum, MiR-214 was found to be over-expressed [50-52]. But, in the cervical cancer tissues [53], multiple melanoma [54], ovarian [55], hepatocellular carcinomas [56] and bladder cancer [57], miR-214 is frequently down-regulated. A high MiR-214 level was also detected in the non-small cell lung cancer cell lines resistant to doxorubicin [58]. In general, overexpression of MiR-214 inhibited cancer cell proliferation and induced apoptosis [55]. MiR-214 itself is also transcriptionally regulated by transcription factors, peroxisome proliferator-activated receptor- $\alpha$ (PPAR $\alpha$ ), hypoxia-inducible factor- $1 \alpha$ (HIF- $1 \alpha)$, and it also is involved in the post-transcriptional regulation of gene expression in multicellular organisms by affecting both the stability and translation of mRNAs [59]. Because of the essential roles of MiR-214 in coordinating tumor proliferation, stemness, angiogenesis, invasiveness, extravasation, metastasis, resistance to chemotherapy, and microenvironment, MiR-214 becomes a molecular hub involved in the control of cancer networks. MiR214 switching in diverse forms of cancer either by its upregulation or downregulation sheds light on the mechanism of its tumorigenic and suppressive roles and has resulted in it being a potential diagnostic/prognostic biomarker and target for therapeutic intervention [48].

MiR-199a is also transcribed as antisense of dynamin 3 (chromosome 1q24.3). Hypermethylation of this region was deemed to correlate with miR-199a in testicular cancer cells and leaded to suppression of cell growth, cancer migration, invasion and metastasis [60]. Like MiR-214, MiR-199a is also either up-regulated or 
down-regulated in a variety of cancers. For example, it is downregulated in human HCC, liver cancer cells [61] and in testicular germ cell tumor (TGCT) [62]. Interestingly, MiR-199a and miR-214 were concordantly expressed in a human neuron-committed teratocarcinoma NT2 cell line and TGCT patient tissue samples [62]. MiR199a and MiR-199b (MiR-199a/b) family of miRNAs are conserved within their intronic sequences [63]. The miR-199a/b family is composed of three members, MiR-199a1, MiR-199a2 and MiR-199b, which are transcribed from conserved antisense intronic transcripts of the DNM2 locus (human chromosome 19), DNM3 locus (human chromosome 1) and DNM1 locus (human chromosome 9), respectively. MiR-199a and b regulate endocytic transport by controlling the expression of important mediators of endocytosis such as clathrin heavy chain, Rab5A, low-density lipoprotein receptor (LDLR), and caveolin-1 (Cav-1) [63]. One of the two mature microRNA species derived from MiR-199a, named MiR$199 a-5 p$ is associated with tumor malignancy. Both MiR199a and b-5p, inhibit clathrin-mediated endocytosis through the regulation of clathrin heavy chain, Rab5A and Rab21 expression, affecting the normal function of receptors located in the plasma membrane such as LDLR and transferrin receptor. In summary, MiR-199a/ $\mathrm{b}-5 \mathrm{p}$ regulates related physiological processes to those controlled by the host genes in which they are encoded and a significant number of predicted target genes for MiR-199a/b-5p were associated with cellular transport [63]. Moreover, MiR-199a/MiR-214 forms miR-199a/ miR-214/PSMD10/TP53/DNMT1 self-regulatory network [62], which might be a potential therapeutic target in the treatment of TGCT [62]. Interestingly, MiR-199a encoded from the opposite strand of dynamin 2 gene DNM2 exerts reciprocal negative regulation upon HIF- $1 \alpha$ and HIF- $2 \alpha$ [64]. Overexpression of MiR-199a decreased HIF-1 $\alpha$ and HIF- $2 \alpha$, cell migration, and metastasis, thus, serves as a regulatory loop between endocytic pathway and hypoxic response in tumor cells. Mir-199a has also been implicated to modulate intracellular iron levels by targeting HIF and indirectly affecting the tumor microenvironment through suppression of lysyl oxidase protein expression in ovarian cancer cells [64].

Apart from MiR-214, MiR-3120 is also encoded from a single gene locus of the dynamin 3 gene, under certain conditions, due to imperfect base pairing. MiR214 and MiR-3120 are the two distinct microRNAs produced from the fully complementary DNA strands. MiR-3120 is produced following transcription and mRNA processing, whereas MiR-214 is produced by antisense transcription. MiR-3120 regulates heat shock cognate protein 70 , thus it serves as a mirror microRNA regulating endocytic function of $\mathrm{Hsc} 70$ and auxilin as well as their expression to influence vesicle uncoating. MiR-3120 is also known to prevent uncoating of clathrincoated vesicles, and MiR-214 is known to target PTEN (phosphatase and tensinhomolog), which interacts with dynamin and regulates synaptic proteins involved in receptor cycling and synaptic plasticity [65]. Despite MiR3120 being regulator for endocytosis pathways, it is not known whether there is any direct modulation role in the tumorigenosis.

\section{THERAPEUTIC POTENTIAL OF DYNAMIN-RELATED PROTEINS}

Dynamin-related proteins are a group of GTPbinding proteins containing good conservation of the five domains architectures defined for classical dynamin. The five domains contained by classical dynamin are the followings: GTPase domain; middle domain; pleckstrinhomology (PH) domain; effector domain (GED); prolinerich domain (PRD) (Figure 2B). Dynamin-related protein proteins also function in vesicle budding, trafficking and membrane-scission events. These proteins have similarity in some domains but might miss out several and have additional domain conferring distinct roles.

\section{Dynamin-related protein 1 (Drp1) as a therapeutic target}

Drp1, an $80 \mathrm{kDa}$ GTPase without the PRD (Figure 2B), is involved in mitochondrial fission and anti-cancer drug-mediated cytotoxicity, implicating an association with cancer progression [25]. Drp1 is also involved in conferring chemotherapy resistance, cell cycle progression, genome instability, cell migration and apoptosis. It is upregulated in certain types of cancerssuch as lung and breast cancer $[25,26,66]$. Drp1 upregulation and activation induce changes in mitochondrial dynamics crucial to confer the drug resistant in T-cell acute lymphoblastic leukemia cells [67]. The influence of mitochondria on human health and disease and mitochondrial dysfunction in cancer has expanded to include defects in mitochondrial genomics and biogenesis, apoptotic signalling and mitochondrial dynamics [68]. Moreover, defects in mitochondrial fission protein Drp1 are linked to apoptotic resistance and autophagy in a lung cancer model [69]. It has been implicated that drugs targeting to Drp1-mediated mitochondrial fission prevents tumor cell cycle progression. Thus, Drp1 inhibition, or Drp1 knockdown resulted in an observed reduction of cancer cell proliferation and an increase of spontaneous apoptosis and thus serves as an effective therapy for cancer treatment [26]. Drp1 is also found to contribute to the migration of human glioblastoma cells under hypoxia, and causes the poor prognosis of glioblastoma due to its mitochondrial control in brain tumor initiating cells [70]. Nuclear Drp1 may increase drug resistance during hypoxia. Drp1 co-precipitated protein, the human homologue of the yeast repair protein RAD23 (hHR23A), is essential 
for nuclear transportation of Drp1 [71]. Meanwhile, the nuclear and nucleolar Drp1 (Drp1nuc) are associated with poor cancer prognosis [71]. In brain cancer, Drp1 controls the migration and neuronal differentiation of subventricular zone-derived neural progenitor cells [72]. Inhibiting Drp1 activity induces alteration of the typical migratory cell morphology into round shapes while the polarized mitochondrial distribution was maintained. With these changes, adult neural stem cells (aNSCs) derived from the subventricular zone of the brain failed to migrate, and neuronal differentiation was prevented [73]. Targeting Drp1 activity by genetic approach or pharmacologic inhibitors attenuates growth of stem-like tumors and lead to good prognosis [74], thus, Drp1 serves as a potential target for cancer treatment.

\section{Mitofusin (Mfn) as a therapeutic target}

Mfn 1 and Mfn 2 are involved in fusion between mitochondria by tethering adjacent mitochondria (Figure 2B). These proteins have two transmembrane segments that anchor to the mitochondrial outer membrane. Mfn1 and Mfn2 exist as both homotypic and heterotypic oligomers, and therefore can cooperate as well as act individually to promote mitochondrial fusion. Each isoform is essential for embryonic development and mitochondrial fusion, and both have distinct and redundant functions to promote mitochondrial fusion [17]. Mutations in mitofusin proteins result in fragmented mitochondria, but this can be reversed by mutations in mammalian Drp1. Human lung cancer cell lines exhibit an imbalanced expression level of Drp1/Mfn2, which promotes a state of mitochondrial fission [25]. Lung tumor tissue samples from patients demonstrated a similar increase in Drp1 and decrease in Mfn2 when compared to adjacent healthy lung. Furthermore, Drp1 also regulates cell cycle progression, genome instability, cell migration and apoptosis in cancer cells. These findings raise the possibility of targeting Drp1-mediated mitochondrial fission as an effective therapy for treating cancer [26].

\section{Dynamin-like GTPase Opa1 as a therapeutic target}

Another dynamin family members called Opa1, is localized on mitochondrial intermembrane space, where it facilitates fusion between mitochondria [21]. In various forms of cancer, Opal is highly expressed and indicates poor prognosis (Table 1). The mitochondria fusion protein Opal expression level is critical in determining the sensitivity of HCC to sorafenib-induced apoptosis in HCC treatment [75] and decreased expression of Opa1 is associated with the treatment of HCC by sorafenib, a multi-kinase inhibitor [75].

\section{DYNAMIN-TARGETED INHIBITORS FOR CANCER TREATMENT}

Targeting dynamin function has great potential to produce a safe therapy to hopefully increase the life expectancy and quality of life for cancer patients. Some dynamin inhibitors have already been moved from the lab into clinical trials. The specificity and potency are the major selection criteria for basic and therapeutic proposes.

Dynamin inhibitors represent a new class of targeted anti-mitotic compounds (Table 2). They are a small but expanding 'palette' of compounds available to rapidly and reversibly block dynamin via distinct mechanisms of action, by operating at different stages in its cycle of GTPase activity. Overall, they possess both antimitotic and anticancer effects. The first reported dynamin inhibitors were long-chain ammonium salts called MiTMAB ${ }^{\mathrm{TM}}$ compounds [76], and then, followed by dimeric tyrphostins [77], and a series of room temperature ionic liquids (RTILs) [78]. Two of the most potent inhibitors from the long-chain ammonium salts, myristyl trimethyl ammonium bromide (MiTMAB) and octadecyltrimethyl ammonium bromide (OcTMAB), are potent and reversible inhibitors of endocytosis in neuronal and non-neuronal cells, and selectively block dynamin's second function in cytokinesis [79]. Targeting cytokinesis with dynamin inhibitors may be a promising new approach for the treatment of cancer [80, 81]. MiTMABs inhibit dynamin GTPase activity by targeting its $\mathrm{PH}$ domain, a module common to many proteins. In contrast to the classical (e.g. taxol) and targeted (e.g. aurora kinase and polo-like kinases inhibitors) anti-mitotic compounds which aim to disrupt the mitotic spindle, advantages of MiTMABs is that it is a cell-permeable, water soluble dynamin 1 and 2 inhibitor which exclusively block cytokinesis without disrupting progression through any other stage of mitosis [80]. Apart from inducing cytokinesis failure, MiTMABs also induce apoptosis in cancer cells [82]. Overall, MiTMABs are highly cytotoxic and possess antiproliferative properties, which seem to be selective for cancer cells.

In contrast to MiTMAB, OcTMAB blocks dynamin recruitment to membranes whereas the Dynole ${ }^{\mathrm{TM}}$ compounds and dynasore block dynamin after its recruitment [83]. Dynoles cause cytokinesis failure by blocking abscission, which is consistent with inhibition of dynamin 2. Dynole 34-2 is a novel antimitotic compound which specifically acts at the abscission stage and selectively targets dividing cells. It is a dynamin inhibitor and is proved to be the most potent compound for cytokinesis failure [83]. The dynoles are thought to bind an allosteric site in the GTPase domain and are expected to be more efficacious and have less off-target effects than MiTMABs. Inhibition of dynamin by dynole 34-2 induces cell death following cytokinesis failure in a range of cancer cells, such as cellosaurus cell line SMA-560, 
paediatric solid tumor line SJ-G2 (glioblastoma), colon cancer cell line SW480, breast cancer cell line MCF-7, human ovarian A2780 cancer cells and HeLa cells [81].

Dynasore and its derivatives are also suitable candidates for potent anti-cancer drugs. Dynasore is a non-competitive inhibitor which dose-dependently inhibits the GTPase activity of dynamin 1 and 2, and presumably at higher doses, other dynamin family members. It also interfered with the in vitro GTPase activity of Drp1 [84]. For instance, dynamic remodelling of actin filaments is the basis for a variety of cellular events including cell motility, cancer cell invasion, and the regulation of actin dynamics [85]. Furthermore, invasion activity of H1080 cell, a lung cancer cell line, was suppressed by approximately $40 \%$ with dynasore treatment [86]. These results strongly suggest that dynasore potently destabilizes F-actin. Notably, dynasore destabilizes F-actin and inhibits serum-induced lamellipodia formation in cells, disrupts co-localization of dynamin 2 and cortactin and inhibits invasion of lung cancer cell line H1080 [86]. Dynago are greatly improved dynasore analogues with greatly reduced or no non-specific in vitro binding and improved potency, they are more potent than dynasore and more specific, blocking dynamin function after its recruitment, with more versatile cell biology tools with reduced cytotoxicity. Among them, Dyngo-4a is the most potent one with 37 fold more potent than dynasore [78].

Two Drp1 inhibitors, mitochondrial division inhibitor 1 (mdivi1) or MiR-499, are potent in inhibition of mitochondrial division [87]. Mdivil is a selective cellpermeable inhibitor of mitochondrial division Drp1 and dynamin 1. It enhances death receptor-mediated apoptosis in human ovarian cancer cells and is able to increase the sensitivity of human ovarian cancer cells to death receptor ligands including TRAIL, FAS ligands, and TNF- $\alpha$ [88]. It has been reported to enhance the apoptotic effect of the death receptor ligand TRAIL in human ovarian cancer [57]. Low serum MiR-499 expression was associated with advanced tumor node metastasis (TNM) stage and poor prognosis [89]. Overexpression of MiR-499-5p inhibited cell proliferation and induced apoptosis in vitro as well as in vivo. Thus, it functions as a tumor suppressor [90]. Other drugs such as micheliolide may also influence Drp1 function. Micheliolide is a guaianolide sesquiterpene lactone, which induced Drp1-mediated cell death in breast cancer cells (MCF-7) through the reactive oxygen species mediated mitochondrial apoptotic pathway [57]. Other dynamin inhibitors include a group of antidepressant drugs which have anti-proliferative activity, for example, sertraline which significantly inhibited tumor growth in CD1 nude mice xenografted subcutaneously with HT29 cells and has also been successfully used in cancer patients [91]. The mechanism involved could possibly be that this group of inhibitors block dynamin activity and inhibit endocytosis in tumor cells, as observed in HeLa and human neuroblastoma SH-Sy5Y cells [92]. Chlorpromazine marketed under the trade names Thorazine and Largactil among others, is a cationic amphiphilic phenothiazinederived anti-psychotic drug which inhibits endocytosis by blocking dynamin 2 function [93]. Apart from abovenoted dynamin inhibitors, chlorpromazine has been shown to have a relative high specificity for brain cancer [94, 95]. Moreover, it has been proven to inhibit glioblastoma growth in rat brains when used in combination with Nitrosureas. Phenothiazine-derived antipsychotic drugs (APDs), which are the cationic amphi-pathic drugs, also inhibit clathrin-mediated endocytosis [93]. It is proposed that potent dynamin inhibition is a shared characteristic of phenothiazine-derived APDs, but not other typical or atypical APDs [93].

Successful cancer treatment requires multiple approaches to reach the most effectiveness. For example, no single combination regimen has clearly emerged as a favourite for the treatment of recurrent or progressive glioblastoma. For instance, the newly diagnosed glioblastoma is now commonly treated with surgery, if feasible, or biopsy, followed by radiation plus concomitant and adjuvant temozolomide, the drug serves as the first line treatment for glioblastoma. However, only approximately one-half of patients respond to temozolomide as it showed little effect in elderly patients with advanced age. Nitrosoureas only remain a second-line treatment option in single and combination regimens, and temozolomide in combination with cisplatin, fotemustine, interferon, sorafenib, celecoxib, irinotecan, or procarbazine/ lomustine/vincristine has not been demonstrated to be more effective than temozolomide alone [96]. Similarly, HER1/EGFR tyrosine kinase inhibitors such as erlotinib or gefitinib are the most clinically advanced HER1/ EGFR-targeted agents for the treatment of glioblastoma. However, both inhibitors only treat a fraction of patients because HER1/EGFR are only overexpressed in these patients [97]. The newly developed inhibitors for dynamin and its related proteins might offer an alternative option for combination of therapeutics to achieve the synergistic effectiveness for glioblastoma.

\section{CONCLUSIONS AND PERSEPCTIVES}

To conclude, dysregulation of endocytosis has been accepted as an emerging feature of cancer development. Significant evidence points to dynamins and theirrelated proteins as having an important function in carcinogenesis. Each dynamin isoform contributes to various types of cancer development by regulating endocytosis, cytokinesis, cell migration, invasion, and prognosis. In general, dynamin 1 and 2 are overexpressed in cancerous tissue and each is related to specific cancer types. Targeted therapeutics are required to decrease their expression levels or prevent the hypermethylation of the dynamin 3 gene or inhibitors selectively block the signalling cascades would be beneficial. Dynamin 3 
serves as a tumor suppressor in hepatocellular carcinoma pathogenesisis and its expression is decreased during the disease condition due to gene hypermethylation. Targeted therapeutics are required to improve its expression level or blockade the hypermethylation of the DNM3. Moreover, the expression levels of dynamin gene-related proteins become imbalanced in cancer. These proteins are potential diagnostic/prognostic biomarkers and potential targets for therapeutic intervention. Anti-sense non-coding RNAs for the dynamin gene are bifunctional. Up- or down-regulation of non-coding RNA controls dynamin gene expression and mitochondrial division, to promote tumorigeneses or suppress tumorigenesis. Although numerous dynamin inhibitors have been developed so far, they have failed to selectively block a specific isoform of dynamin. Current dynamin inhibitors are non-selective to a particular isoform, thus, selective inhibitors against distinct isoform are needed for future anti-cancer drug development. The most commonly used dynamin inhibitors have revealed off-target effects in dynamin triple knockout cells [98], warranting future development of isoform-specific inhibitors for dynamin as potential therapeutics for successful anti-cancer treatment.

\section{Abbreviations}

aNSCs, adult neural stem cells; AP2, clathrin adaptor protein 2; APDs, Phenothiazine-derived antipsychotic drugs; BoNTs, botulinum neurotoxins; Cav1, caveolin-1; CCPs, clathrin-coated pits; CME, clathrinmediated endocytosis; CLTC, clathrin heavy chain; DNM1, DNM2 and DNM3. dynamin 1, 2, 3 genes; Drp1, dynamin-related protein 1; EGFR, epidermal growth factor receptor; Fis1, mitochondrial fission 1; GED, GTPase Effector Domain; HCC, hepatocellular carcinoma; LDLR, low-density lipoprotein receptor; mdivi1, mitochondrial division inhibitor 1; MIS, mitochondrial import sequence; MiTMAB, myristyl trimethyl ammonium bromide; MSPPCR, methylation specific polymerase chain reaction; OcTMAB, octadecyltrimethyl ammonium bromide; OPA1, dynamin-like GTPase protein Optic Atrophy 1; PCA, Progressive prostate cancer; $\mathrm{PH}$ domain, pleckstrin homology domain; PRD, proline rich domain; shRNAs, short hairpin RNAs; TRAIL, TNF-related apoptosisinducing ligand.

\section{ACKNOWLEDGMENTS}

Dr. Kim Orange (Dublin City University) is thanked for a critical reading of the manuscript.

\section{CONFLICTS OF INTEREST}

The author declares that there is no conflict of interest.

\section{FUNDING}

Science Foundation Ireland is thanked for funding this research through a Starting Investigator Award (to J.M. Grant Number 15/SIRG/3508T).

\section{REFERENCES}

1. Mayor S, Pagano RE. Pathways of clathrin-independent endocytosis. Nature Reviews Molecular Cell Biology. 2007; 8: 603-12. doi: 10.1038/nrm2216.

2. Doherty GJ, McMahon HT. Mechanisms of Endocytosis. Annual Review of Biochemistry. 2009; 78: 857-902. doi: 10.1146/annurev.biochem.78.081307.110540.

3. Ferguson SM, De Camilli P. Dynamin, a membraneremodelling GTPase. Nat Rev Mol Cell Biol. 2012; 13: 7588. doi: 10.1038/nrm3266.

4. Meng J, Wang J, Lawrence GW, Dolly JO. Molecular components required for resting and stimulated endocytosis of botulinum neurotoxins by glutamatergic and peptidergic neurons. FASEB J. 2013; 27: 3167-80. doi: 10.1096/fj.13228973.

5. Bauerfeind R, Takei K, De Camilli P. Amphiphysin I is associated with coated endocytic intermediates and undergoes stimulation-dependent dephosphorylation in nerve terminals. J Biol Chem. 1997; 272: 30984-92.

6. Liu JP, Sim AT, Robinson PJ. Calcineurin inhibition of dynamin I GTPase activity coupled to nerve terminal depolarization. Science. 1994; 265: 970-3.

7. Reis CR, Chen PH, Srinivasan S, Aguet F, Mettlen M, Schmid SL. Crosstalk between Akt/GSK3beta signaling and dynamin-1 regulates clathrin-mediated endocytosis. EMBO J. 2015; 34: 2132-46. doi: 10.15252/embj.201591518.

8. Reis CR, Chen PH, Bendris N, Schmid SL. TRAIL-death receptor endocytosis and apoptosis are selectively regulated by dynamin-1 activation. Proc Natl Acad Sci U S A. 2017. doi: 10.1073/pnas.1615072114.

9. Gonzalez-Jamett AM, Momboisse F, Haro-Acuna V, Bevilacqua JA, Caviedes P, Cardenas AM. Dynamin-2 function and dysfunction along the secretory pathway. Front Endocrinol (Lausanne). 2013; 4: 126. doi: 10.3389/ fendo.2013.00126.

10. Liu YW, Neumann S, Ramachandran R, Ferguson SM, Pucadyil TJ, Schmid SL. Differential curvature sensing and generating activities of dynamin isoforms provide opportunities for tissue-specific regulation. Proc Natl Acad Sci U S A. 2011; 108: E234-42. doi: 10.1073/ pnas. 1102710108 .

11. Ferguson SM, Brasnjo G, Hayashi M, Wolfel M, Collesi C, Giovedi S, Raimondi A, Gong LW, Ariel P, Paradise $\mathrm{S}$, O’Toole E, Flavell R, Cremona O, et al. A selective activity-dependent requirement for dynamin 1 in synaptic vesicle endocytosis. Science. 2007; 316: 570-4. doi: 10.1126/science. 1140621 . 
12. Liu YW, Surka MC, Schroeter T, Lukiyanchuk V, Schmid SL. Isoform and splice-variant specific functions of dynamin-2 revealed by analysis of conditional knock-out cells. Mol Biol Cell. 2008; 19: 5347-59. doi: 10.1091/mbc. E08-08-0890.

13. Raimondi A, Ferguson SM, Lou X, Armbruster M, Paradise S, Giovedi S, Messa M, Kono N, Takasaki J, Cappello V, O'Toole E, Ryan TA, De Camilli P. Overlapping role of dynamin isoforms in synaptic vesicle endocytosis. Neuron. 2011; 70: 1100-14. doi: 10.1016/j.neuron.2011.04.031.

14. Singh M, Jadhav HR, Bhatt T. Dynamin Functions and Ligands: Classical Mechanisms Behind. Mol Pharmacol. 2017; 91: 123-34. doi: 10.1124/mol.116.105064.

15. Ingerman E, Perkins EM, Marino M, Mears JA, McCaffery JM, Hinshaw JE, Nunnari J. Dnm1 forms spirals that are structurally tailored to fit mitochondria. J Cell Biol. 2005; 170: 1021-7. doi: 10.1083/jcb.200506078.

16. Loson OC, Song Z, Chen H, Chan DC. Fis1, Mff, MiD49, and MiD51 mediate Drp1 recruitment in mitochondrial fission. Mol Biol Cell. 2013; 24: 659-67. doi: 10.1091/mbc. E12-10-0721.

17. Chen H, Detmer SA, Ewald AJ, Griffin EE, Fraser SE, Chan DC. Mitofusins Mfn1 and Mfn2 coordinately regulate mitochondrial fusion and are essential for embryonic development. J Cell Biol. 2003; 160: 189-200. doi: 10.1083/ jcb.200211046.

18. Ishihara N, Eura Y, Mihara K. Mitofusin 1 and 2 play distinct roles in mitochondrial fusion reactions via GTPase activity. J Cell Sci. 2004; 117: 6535-46. doi: 10.1242/ jes.01565.

19. Santel A, Frank S, Gaume B, Herrler M, Youle RJ, Fuller MT. Mitofusin-1 protein is a generally expressed mediator of mitochondrial fusion in mammalian cells. J Cell Sci. 2003; 116: 2763-74. doi: 10.1242/jcs.00479.

20. Cao YL, Meng S, Chen Y, Feng JX, Gu DD, Yu B, Li YJ, Yang JY, Liao S, Chan DC, Gao S. MFN1 structures reveal nucleotide-triggered dimerization critical for mitochondrial fusion. Nature. 2017. doi: 10.1038/nature21077.

21. Griparic L, Kanazawa T, van der Bliek AM. Regulation of the mitochondrial dynamin-like protein Opa1 by proteolytic cleavage. J Cell Biol. 2007; 178: 757-64. doi: 10.1083/ jcb.200704112.

22. Ishihara N, Fujita Y, Oka T, Mihara K. Regulation of mitochondrial morphology through proteolytic cleavage of OPA1. EMBO J. 2006; 25: 2966-77. doi: 10.1038/ sj.emboj.7601184.

23. Ranieri M, Brajkovic S, Riboldi G, Ronchi D, Rizzo F, Bresolin N, Corti S, Comi GP. Mitochondrial fusion proteins and human diseases. Neurol Res Int. 2013; 2013: 293893. doi: 10.1155/2013/293893.

24. Belenguer P, Pellegrini L. The dynamin GTPase OPA1: more than mitochondria? Biochim Biophys Acta. 2013; 1833: 176-83. doi: 10.1016/j.bbamcr.2012.08.004.

25. Rehman J, Zhang HJ, Toth PT, Zhang Y, Marsboom G,
Hong Z, Salgia R, Husain AN, Wietholt C, Archer SL. Inhibition of mitochondrial fission prevents cell cycle progression in lung cancer. FASEB J. 2012; 26: 2175-86. doi: 10.1096/fj.11-196543.

26. Qian W, Wang J, Van Houten B. The role of dynaminrelated protein 1 in cancer growth: a promising therapeutic target? Expert Opin Ther Targets. 2013; 17: 997-1001. doi: 10.1517/14728222.2013.823160.

27. Fang HY, Chen CY, Chiou SH, Wang YT, Lin TY, Chang HW, Chiang IP, Lan KJ, Chow KC. Overexpression of optic atrophy 1 protein increases cisplatin resistance via inactivation of caspase-dependent apoptosis in lung adenocarcinoma cells. Hum Pathol. 2012; 43: 105-14. doi: 10.1016/j.humpath.2011.04.012.

28. Atkins K, Dasgupta A, Chen KH, Mewburn J, Archer SL. The role of Drp1 adaptor proteins MiD49 and MiD51 in mitochondrial fission: implications for human disease. Clin Sci (Lond). 2016; 130: 1861-74. doi: 10.1042/CS20160030.

29. Kelly BL, Vassar R, Ferreira A. Beta-amyloid-induced dynamin 1 depletion in hippocampal neurons. A potential mechanism for early cognitive decline in Alzheimer disease. J Biol Chem. 2005; 280: 31746-53. doi: 10.1074/ jbc.M503259200.

30. Haferlach T, Kohlmann A, Wieczorek L, Basso G, Kronnie GT, Bene MC, De Vos J, Hernandez JM, Hofmann WK, Mills KI, Gilkes A, Chiaretti S, Shurtleff SA, et al. Clinical utility of microarray-based gene expression profiling in the diagnosis and subclassification of leukemia: report from the International Microarray Innovations in Leukemia Study Group. J Clin Oncol. 2010; 28: 2529-37. doi: 10.1200/ JCO.2009.23.4732.

31. Hamao K, Morita M, Hosoya H. New function of the proline rich domain in dynamin-2 to negatively regulate its interaction with microtubules in mammalian cells. Exp Cell Res. 2009; 315: 1336-45. doi: 10.1016/j.yexcr.2009.01.025.

32. Normanno N, De Luca A, Bianco C, Strizzi L, Mancino M, Maiello MR, Carotenuto A, De Feo G, Caponigro F, Salomon DS. Epidermal growth factor receptor (EGFR) signaling in cancer. Gene. 2006; 366: 2-16. doi: 10.1016/j. gene.2005.10.018.

33. Gong C, Zhang J, Zhang L, Wang Y, Ma H, Wu W, Cui J, Wang Y, Ren Z. Dynamin2 downregulation delays EGFR endocytic trafficking and promotes EGFR signaling and invasion in hepatocellular carcinoma. Am J Cancer Res. 2015; 5: 702-13.

34. Sousa LP, Lax I, Shen H, Ferguson SM, De Camilli P, Schlessinger J. Suppression of EGFR endocytosis by dynamin depletion reveals that EGFR signaling occurs primarily at the plasma membrane. Proc Natl Acad Sci U S A. 2012; 109: 4419-24. doi: 10.1073/pnas. 1200164109.

35. Ezratty EJ, Bertaux C, Marcantonio EE, Gundersen GG. Clathrin mediates integrin endocytosis for focal adhesion disassembly in migrating cells. J Cell Biol. 2009; 187: 73347. doi: $10.1083 /$ jcb.200904054. 
36. Chao WT, Kunz J. Focal adhesion disassembly requires clathrin-dependent endocytosis of integrins. FEBS Lett. 2009; 583: 1337-43. doi: 10.1016/j.febslet.2009.03.037.

37. Roy UK, Rial NS, Kachel KL, Gerner EW. Activated K-RAS increases polyamine uptake in human colon cancer cells through modulation of caveolar endocytosis. Mol Carcinog. 2008; 47: 538-53. doi: 10.1002/mc.20414.

38. Minois N, Carmona-Gutierrez D, Madeo F. Polyamines in aging and disease. Aging (Albany NY). 2011; 3: 716-32. doi: 10.18632/aging.100361.

39. Xu B, Teng LH, Silva SD, Bijian K, Al Bashir S, Jie S, Dolph M, Alaoui-Jamali MA, Bismar TA. The significance of dynamin 2 expression for prostate cancer progression, prognostication, and therapeutic targeting. Cancer Med. 2014; 3: 14-24. doi: 10.1002/cam4.168.

40. Lee YY, Jeon HK, Lee J, Hong JE, Do IG, Choi CH, Kim TJ, Kim BG, Bae DS, Kim YC, Lee JW. Dynamin 2 Inhibitors as Novel Therapeutic Agents Against Cervical Cancer Cells. Anticancer Res. 2016; 36: 6381-8. doi: 10.21873/anticanres.11235.

41. Baldassarre M, Pompeo A, Beznoussenko G, Castaldi C, Cortellino S, McNiven MA, Luini A, Buccione R. Dynamin participates in focal extracellular matrix degradation by invasive cells. Mol Biol Cell. 2003; 14: 1074-84. doi: 10.1091/mbc.E02-05-0308.

42. Razidlo GL, Wang Y, Chen J, Krueger EW, Billadeau DD, McNiven MA. Dynamin 2 potentiates invasive migration of pancreatic tumor cells through stabilization of the Rac1 GEF Vav1. Dev Cell. 2013; 24: 573-85. doi: 10.1016/j. devcel.2013.02.010.

43. Gomez TS, Hamann MJ, McCarney S, Savoy DN, Lubking CM, Heldebrant MP, Labno CM, McKean DJ, McNiven MA, Burkhardt JK, Billadeau DD. Dynamin 2 regulates T cell activation by controlling actin polymerization at the immunological synapse. Nat Immunol. 2005; 6: 261-70. doi: 10.1038/ni1168.

44. Hobert O, Schilling JW, Beckerle MC, Ullrich A, Jallal B. $\mathrm{SH} 3$ domain-dependent interaction of the proto-oncogene product Vav with the focal contact protein zyxin. Oncogene. 1996; 12: 1577-81.

45. Feng H, Liu KW, Guo P, Zhang P, Cheng T, McNiven MA, Johnson GR, Hu B, Cheng SY. Dynamin 2 mediates PDGFRalpha-SHP-2-promoted glioblastoma growth and invasion. Oncogene. 2012; 31: 2691-702. doi: 10.1038/ onc. 2011.436

46. Zhang Z, Chen C, Guo W, Zheng S, Sun Z, Geng X. DNM3 Attenuates Hepatocellular Carcinoma Growth by Activating P53. Med Sci Monit. 2016; 22: 197-205.

47. Inokawa $\mathrm{Y}$, Nomoto $\mathrm{S}$, Hishida M, Hayashi M, Kanda M, Nishikawa Y, Takeda S, Fujiwara M, Koike M, Sugimoto H, Fujii T, Nakayama G, Yamada S, et al. Dynamin 3: a new candidate tumor suppressor gene in hepatocellular carcinoma detected by triple combination array analysis. Onco Targets Ther. 2013; 6: 1417-24. doi: 10.2147/OTT.
S51913.

48. Penna E, Orso F, Taverna D. miR-214 as a key hub that controls cancer networks: small player, multiple functions. J Invest Dermatol. 2015; 135: 960-9. doi: 10.1038/ jid.2014.479.

49. Zhang M, Du X. Noncoding RNAs in gastric cancer: Research progress and prospects. World J Gastroenterol. 2016; 22: 6610-8. doi: 10.3748/wjg.v22.i29.6610.

50. Kutanzi KR, Yurchenko OV, Beland FA, Checkhun VF, Pogribny IP. MicroRNA-mediated drug resistance in breast cancer. Clin Epigenetics. 2011; 2: 171-85. doi: 10.1007/ s13148-011-0040-8.

51. Xu CX, Xu M, Tan L, Yang H, Permuth-Wey J, Kruk PA, Wenham RM, Nicosia SV, Lancaster JM, Sellers TA, Cheng JQ. MicroRNA miR-214 regulates ovarian cancer cell stemness by targeting p53/Nanog. J Biol Chem. 2012; 287: 34970-8. doi: 10.1074/jbc.M112.374611.

52. Phatak P, Byrnes KA, Mansour D, Liu L, Cao S, Li R, Rao JN, Turner DJ, Wang JY, Donahue JM. Overexpression of miR-214-3p in esophageal squamous cancer cells enhances sensitivity to cisplatin by targeting survivin directly and indirectly through CUG-BP1. Oncogene. 2016; 35: 2087 97. doi: 10.1038/onc.2015.271.

53. Wang F, Liu M, Li X, Tang H. MiR-214 reduces cell survival and enhances cisplatin-induced cytotoxicity via down-regulation of Bcl212 in cervical cancer cells. FEBS Lett. 2013; 587: 488-95. doi: 10.1016/j.febslet.2013.01.016.

54. Misiewicz-Krzeminska I, Sarasquete ME, Quwaider D, Krzeminski P, Ticona FV, Paino T, Delgado M, Aires A, Ocio EM, Garcia-Sanz R, San Miguel JF, Gutierrez NC. Restoration of microRNA-214 expression reduces growth of myeloma cells through positive regulation of P53 and inhibition of DNA replication. Haematologica. 2013; 98: 640-8. doi: 10.3324/haematol.2012.070011.

55. Liu Y, Zhou H, Ma L, Hou Y, Pan J, Sun C, Yang Y, Zhang J. MiR-214 suppressed ovarian cancer and negatively regulated semaphorin 4D. Tumour Biol. 2016; 37: 823948. doi: 10.1007/s13277-015-4708-0.

56. Xia H, Ooi LL, Hui KM. MiR-214 targets beta-catenin pathway to suppress invasion, stem-like traits and recurrence of human hepatocellular carcinoma. PLoS One. 2012; 7: e44206. doi: 10.1371/journal.pone.0044206.

57. Jia Y, Zhou L, Tian C, Shi Y, Wang C, Tong Z. Dynaminrelated protein 1 is involved in micheliolide-induced breast cancer cell death. Onco Targets Ther. 2015; 8: 3371-81. doi: 10.2147/OTT.S91805.

58. Salim H, Akbar NS, Zong D, Vaculova AH, Lewensohn R, Moshfegh A, Viktorsson K, Zhivotovsky B. miRNA-214 modulates radiotherapy response of non-small cell lung cancer cells through regulation of p38MAPK, apoptosis and senescence. Br J Cancer. 2012; 107: 1361-73. doi: 10.1038/ bjc.2012.382.

59. Wong RW, Gonsalves MN, Huber ML, Rich L, Strom A. Erythrocyte and Biochemical Abnormalities as Diagnostic 
Markers in Dogs With Hemangiosarcoma Related Hemoabdomen. Vet Surg. 2015; 44: 852-7. doi: 10.1111/ vsu. 12361.

60. Cheung HH, Davis AJ, Lee TL, Pang AL, Nagrani S, Rennert OM, Chan WY. Methylation of an intronic region regulates miR-199a in testicular tumor malignancy. Oncogene. 2011; 30: 3404-15. doi: 10.1038/onc.2011.60.

61. Duan Q, Wang X, Gong W, Ni L, Chen C, He X, Chen F, Yang L, Wang P, Wang DW. ER stress negatively modulates the expression of the miR-199a/214 cluster to regulates tumor survival and progression in human hepatocellular cancer. PLoS One. 2012; 7: e31518. doi: 10.1371/journal.pone.0031518.

62. Chen BF, Suen YK, Gu S, Li L, Chan WY. A miR-199a/ miR-214 self-regulatory network via PSMD10, TP53 and DNMT1 in testicular germ cell tumor. Sci Rep. 2014; 4: 6413. doi: 10.1038/srep06413.

63. Aranda JF, Canfran-Duque A, Goedeke L, Suarez Y, Fernandez-Hernando C. The miR-199-dynamin regulatory axis controls receptor-mediated endocytosis. J Cell Sci. 2015; 128: 3197-209. doi: 10.1242/jcs.165233.

64. Joshi HP, Subramanian IV, Schnettler EK, Ghosh G, Rupaimoole R, Evans C, Saluja M, Jing Y, Cristina I, Roy S, Zeng Y, Shah VH, Sood AK, et al. Dynamin 2 along with microRNA-199a reciprocally regulate hypoxia-inducible factors and ovarian cancer metastasis. Proc Natl Acad Sci U S A. 2014; 111: 5331-6. doi: 10.1073/pnas.1317242111.

65. Scott H, Howarth J, Lee YB, Wong LF, Bantounas I, Phylactou L, Verkade P, Uney JB. MiR-3120 is a mirror microRNA that targets heat shock cognate protein 70 and auxilin messenger RNAs and regulates clathrin vesicle uncoating. J Biol Chem. 2012; 287: 14726-33. doi: 10.1074/ jbc.M111.326041.

66. Zhao J, Zhang J, Yu M, Xie Y, Huang Y, Wolff DW, Abel $\mathrm{PW}, \mathrm{Tu} \mathrm{Y}$. Mitochondrial dynamics regulates migration and invasion of breast cancer cells. Oncogene. 2013; 32: 481424. doi: 10.1038/onc.2012.494.

67. Cai J, Wang J, Huang Y, Wu H, Xia T, Xiao J, Chen X, Li H, Qiu Y, Wang Y, Wang T, Xia H, Zhang Q, et al. ERK/ Drp1-dependent mitochondrial fission is involved in the MSC-induced drug resistance of T-cell acute lymphoblastic leukemia cells. Cell Death Dis. 2016; 7: e2459. doi: 10.1038/cddis.2016.370.

68. Roberts ER, Thomas KJ. The role of mitochondria in the development and progression of lung cancer. Comput Struct Biotechnol J. 2013; 6: e201303019. doi: 10.5936/ csbj.201303019.

69. Thomas KJ, Jacobson MR. Defects in mitochondrial fission protein dynamin-related protein 1 are linked to apoptotic resistance and autophagy in a lung cancer model. PLoS One. 2012; 7: e45319. doi: 10.1371/journal.pone.0045319.

70. Wan YY, Zhang JF, Yang ZJ, Jiang LP, Wei YF, Lai QN, Wang JB, Xin HB, Han XJ. Involvement of Drp1 in hypoxia-induced migration of human glioblastoma
U251 cells. Oncol Rep. 2014; 32: 619-26. doi: 10.3892/ or.2014.3235.

71. Chiang YY, Chen SL, Hsiao YT, Huang CH, Lin TY, Chiang IP, Hsu WH, Chow KC. Nuclear expression of dynamin-related protein 1 in lung adenocarcinomas. Mod Pathol. 2009; 22: 1139-50. doi: 10.1038/ modpathol.2009.83.

72. Kim HJ, Shaker MR, Cho B, Cho HM, Kim H, Kim JY, Sun W. Dynamin-related protein 1 controls the migration and neuronal differentiation of subventricular zone-derived neural progenitor cells. Sci Rep. 2015; 5: 15962. doi: 10.1038/srep15962.

73. Steib K, Schaffner I, Jagasia R, Ebert B, Lie DC. Mitochondria modify exercise-induced development of stem cell-derived neurons in the adult brain. J Neurosci. 2014; 34: 6624-33. doi: 10.1523/JNEUROSCI.4972-13.2014.

74. Xie Q, Wu Q, Horbinski CM, Flavahan WA, Yang K, Zhou W, Dombrowski SM, Huang Z, Fang X, Shi Y, Ferguson AN, Kashatus DF, Bao S, et al. Mitochondrial control by DRP1 in brain tumor initiating cells. Nat Neurosci. 2015; 18: 501-10. doi: 10.1038/nn.3960.

75. Zhao X, Tian C, Puszyk WM, Ogunwobi OO, Cao M, Wang T, Cabrera R, Nelson DR, Liu C. OPA1 downregulation is involved in sorafenib-induced apoptosis in hepatocellular carcinoma. Lab Invest. 2013; 93: 8-19. doi: 10.1038/ labinvest.2012.144.

76. Hill TA, Odell LR, Quan A, Abagyan R, Ferguson G, Robinson PJ, McCluskey A. Long chain amines and long chain ammonium salts as novel inhibitors of dynamin GTPase activity. Bioorg Med Chem Lett. 2004; 14: 3275 8. doi: 10.1016/j.bmcl.2004.03.096.

77. Hill T, Odell LR, Edwards JK, Graham ME, McGeachie AB, Rusak J, Quan A, Abagyan R, Scott JL, Robinson PJ, McCluskey A. Small molecule inhibitors of dynamin I GTPase activity: development of dimeric tyrphostins. J Med Chem. 2005; 48: 7781-8. doi: 10.1021/jm0402081.

78. McCluskey A, Daniel JA, Hadzic G, Chau N, Clayton EL, Mariana A, Whiting A, Gorgani NN, Lloyd J, Quan A, Moshkanbaryans L, Krishnan S, Perera S, et al. Building a better dynasore: the dyngo compounds potently inhibit dynamin and endocytosis. Traffic. 2013; 14: 1272-89. doi: 10.1111/tra.12119.

79. Quan A, McGeachie AB, Keating DJ, van Dam EM, Rusak J, Chau N, Malladi CS, Chen C, McCluskey A, Cousin MA, Robinson PJ. Myristyl trimethyl ammonium bromide and octadecyl trimethyl ammonium bromide are surface-active small molecule dynamin inhibitors that block endocytosis mediated by dynamin I or dynamin II. Mol Pharmacol. 2007; 72: 1425-39. doi: 10.1124/mol.107.034207.

80. Joshi S, Braithwaite AW, Robinson PJ, Chircop M. Dynamin inhibitors induce caspase-mediated apoptosis following cytokinesis failure in human cancer cells and this is blocked by Bcl-2 overexpression. Mol Cancer. 2011; 10: 78. doi: 10.1186/1476-4598-10-78. 
81. Chircop M, Perera S, Mariana A, Lau H, Ma MP, Gilbert J, Jones NC, Gordon CP, Young KA, Morokoff A, Sakoff J, O'Brien TJ, McCluskey A, et al. Inhibition of dynamin by dynole 34-2 induces cell death following cytokinesis failure in cancer cells. Mol Cancer Ther. 2011; 10: 1553-62. doi: 10.1158/1535-7163.MCT-11-0067.

82. Jones RL, Pepling ME. Role of the antiapoptotic proteins BCL2 and MCL1 in the neonatal mouse ovary. Biol Reprod. 2013; 88: 46. doi: 10.1095/biolreprod.112.103028.

83. Hill TA, Gordon CP, McGeachie AB, Venn-Brown B, Odell LR, Chau N, Quan A, Mariana A, Sakoff JA, Chircop M, Robinson PJ, McCluskey A. Inhibition of dynamin mediated endocytosis by the dynoles - synthesis and functional activity of a family of indoles. J Med Chem. 2009; 52: 3762-73. doi: 10.1021/jm900036m.

84. Thompson HM, McNiven MA. Discovery of a new 'dynasore'. Nat Chem Biol. 2006; 2: 355-6. doi: 10.1038/ nchembio0706-355.

85. Yamada H, Abe T, Li SA, Tago S, Huang P, Watanabe M, Ikeda S, Ogo N, Asai A, Takei K. N'-[4-(dipropylamino) benzylidene]-2-hydroxybenzohydrazide is a dynamin GTPase inhibitor that suppresses cancer cell migration and invasion by inhibiting actin polymerization. Biochem Biophys Res Commun. 2014; 443: 511-7. doi: 10.1016/j. bbrc.2013.11.118.

86. Yamada H, Abe T, Li SA, Masuoka Y, Isoda M, Watanabe M, Nasu Y, Kumon H, Asai A, Takei K. Dynasore, a dynamin inhibitor, suppresses lamellipodia formation and cancer cell invasion by destabilizing actin filaments. Biochem Biophys Res Commun. 2009; 390: 1142-8. doi: 10.1016/j.bbrc.2009.10.105.

87. Rosdah AA, Holien JK, Delbridge LM, Dusting GJ, Lim SY. Mitochondrial fission - a drug target for cytoprotection or cytodestruction? Pharmacol Res Perspect. 2016; 4: e00235. doi: 10.1002/prp2.235.

88. Wang J, Hansen K, Edwards R, Van Houten B, Qian W. Mitochondrial division inhibitor 1 (mdivi-1) enhances death receptor-mediated apoptosis in human ovarian cancer cells. Biochem Biophys Res Commun. 2015; 456: 7-12. doi: 10.1016/j.bbrc.2014.11.010.

89. Li M, Zhang Q, Wu L, Jia C, Shi F, Li S, Peng A, Zhang G, Song X, Wang C. Serum miR-499 as a novel diagnostic and prognostic biomarker in non-small cell lung cancer. Oncol Rep. 2014; 31: 1961-7. doi: 10.3892/or.2014.3029.

90. Li M, Zhang S, Wu N, Wu L, Wang C, Lin Y. Overexpression of miR-499-5p inhibits non-small cell lung cancer proliferation and metastasis by targeting VAV3. Sci Rep. 2016; 6: 23100. doi: 10.1038/srep23100.

91. Gil-Ad I, Zolokov A, Lomnitski L, Taler M, Bar M, Luria D, Ram E, Weizman A. Evaluation of the potential anticancer activity of the antidepressant sertraline in human colon cancer cell lines and in colorectal cancer-xenografted mice. Int J Oncol. 2008; 33: 277-86.

92. Takahashi K, Miyoshi H, Otomo M, Osada K, Yamaguchi
N, Nakashima H. Suppression of dynamin GTPase activity by sertraline leads to inhibition of dynamin-dependent endocytosis. Biochem Biophys Res Commun. 2010; 391: 382-7. doi: 10.1016/j.bbrc.2009.11.067.

93. Daniel JA, Chau N, Abdel-Hamid MK, Hu L, von Kleist L, Whiting A, Krishnan S, Maamary P, Joseph SR, Simpson F, Haucke V, McCluskey A, Robinson PJ. Phenothiazinederived antipsychotic drugs inhibit dynamin and clathrinmediated endocytosis. Traffic. 2015; 16: 635-54. doi: 10.1111/tra.12272.

94. Ban TA. Fifty years chlorpromazine: a historical perspective. Neuropsychiatr Dis Treat. 2007; 3: 495-500.

95. Aas AT, Brun A, Pero RW, Salford LG. Chlorpromazine in combination with nitrosourea inhibits experimental glioma growth. Br J Neurosurg. 1994; 8: 187-92.

96. Weller M, Cloughesy T, Perry JR, Wick W. Standards of care for treatment of recurrent glioblastoma - are we there yet? Neuro Oncol. 2013; 15: 4-27. doi: 10.1093/neuonc/ $\operatorname{nos} 273$

97. Xu YY, Gao P, Sun Y, Duan YR. Development of targeted therapies in treatment of glioblastoma. Cancer Biol Med. 2015; 12: 223-37. doi: 10.7497/j.issn.2095-3941.2015.0020.

98. Park RJ, Shen H, Liu L, Liu X, Ferguson SM, De Camilli P. Dynamin triple knockout cells reveal off target effects of commonly used dynamin inhibitors. J Cell Sci. 2013; 126: 5305-12. doi: 10.1242/jcs.138578.

99. Zhang Y, Nolan M, Yamada H, Watanabe M, Nasu Y, Takei K, Takeda T. Dynamin2 GTPase contributes to invadopodia formation in invasive bladder cancer cells. Biochem Biophys Res Commun. 2016; 480: 409-14. doi: 10.1016/j.bbrc.2016.10.063.

100. Yamada H, Takeda T, Michiue H, Abe T, Takei K. Actin bundling by dynamin 2 and cortactin is implicated in cell migration by stabilizing filopodia in human non-small cell lung carcinoma cells. Int J Oncol. 2016; 49: 877-86. doi: 10.3892/ijo.2016.3592.

101. Rosse C, Lodillinsky C, Fuhrmann L, Nourieh M, Monteiro P, Irondelle M, Lagoutte E, Vacher S, Waharte F, PaulGilloteaux P, Romao M, Sengmanivong L, Linch M, et al. Control of MT1-MMP transport by atypical PKC during breast-cancer progression. Proc Natl Acad Sci U S A. 2014; 111: E1872-9. doi: 10.1073/pnas.1400749111.

102. Ge Z, Li M, Zhao G, Xiao L, Gu Y, Zhou X, Yu MD, Li J, Dovat S, Song C. Novel dynamin 2 mutations in adult T-cell acute lymphoblastic leukemia. Oncol Lett. 2016; 12: 2746-51. doi: 10.3892/ol.2016.4993.

103. Eppinga RD, Krueger EW, Weller SG, Zhang L, Cao H, McNiven MA. Increased expression of the large GTPase dynamin 2 potentiates metastatic migration and invasion of pancreatic ductal carcinoma. Oncogene. 2012; 31: 1228-41. doi: 10.1038/onc.2011.329.

104. van der Bliek AM, Shen Q, Kawajiri S. Mechanisms of mitochondrial fission and fusion. Cold Spring Harb Perspect Biol. 2013; 5. doi: 10.1101/cshperspect.a011072. 
105. Joshi S, Perera S, Gilbert J, Smith CM, Mariana A, Gordon CP, Sakoff JA, McCluskey A, Robinson PJ, Braithwaite AW, Chircop M. The dynamin inhibitors MiTMAB and OcTMAB induce cytokinesis failure and inhibit cell proliferation in human cancer cells. Mol Cancer Ther. 2010; 9: 1995-2006. doi: 10.1158/1535-7163.MCT-10-0161.

106. Robertson MJ, Deane FM, Robinson PJ, McCluskey A. Synthesis of Dynole 34-2, Dynole 2-24 and Dyngo 4a for investigating dynamin GTPase. Nat Protoc. 2014; 9: 85170. doi: 10.1038/nprot.2014.046.

107. Chung CL, Sheu JR, Liu HE, Chang SC, Chou YC, Chen WL, Chou DS, Hsiao G. Dynasore, a dynamin inhibitor, induces PAI-1 expression in MeT-5A human pleural mesothelial cells. Am J Respir Cell Mol Biol. 2009; 40: 692-700. doi: 10.1165/rcmb.2008-0087OC.

108. Kirchhausen T, Macia E, Pelish HE. Use of dynasore, the small molecule inhibitor of dynamin, in the regulation of endocytosis. Methods Enzymol. 2008; 438: 77-93. doi: 10.1016/S0076-6879(07)38006-3.

109. Macia E, Ehrlich M, Massol R, Boucrot E, Brunner C, Kirchhausen T. Dynasore, a cell-permeable inhibitor of dynamin. Dev Cell. 2006; 10: 839-50. doi: 10.1016/j. devcel.2006.04.002.

110. Zaja I, Bai X, Liu Y, Kikuchi C, Dosenovic S, Yan Y, Canfield SG, Bosnjak ZJ. Cdk1, PKCdelta and calcineurinmediated Drp1 pathway contributes to mitochondrial fission-induced cardiomyocyte death. Biochem Biophys Res Commun. 2014; 453: 710-21. doi: 10.1016/j. bbrc.2014.09.144.
111. Manczak M, Reddy PH. Mitochondrial division inhibitor 1 protects against mutant huntingtin-induced abnormal mitochondrial dynamics and neuronal damage in Huntington's disease. Hum Mol Genet. 2015; 24: 7308-25. doi: $10.1093 / \mathrm{hmg} / \mathrm{ddv} 429$.

112. Ishikita A, Matoba T, Ikeda G, Koga J, Mao Y, Nakano K, Takeuchi O, Sadoshima J, Egashira K. NanoparticleMediated Delivery of Mitochondrial Division Inhibitor 1 to the Myocardium Protects the Heart From IschemiaReperfusion Injury Through Inhibition of Mitochondria Outer Membrane Permeabilization: A New Therapeutic Modality for Acute Myocardial Infarction. J Am Heart Assoc. 2016; 5. doi: 10.1161/JAHA.116.003872.

113. Ayanga BA, Badal SS, Wang Y, Galvan DL, Chang BH, Schumacker PT, Danesh FR. Dynamin-Related Protein 1 Deficiency Improves Mitochondrial Fitness and Protects against Progression of Diabetic Nephropathy. J Am Soc Nephrol. 2016; 27: 2733-47. doi: 10.1681/ ASN.2015101096.

114. Hill TA, Mariana A, Gordon CP, Odell LR, Robertson MJ, McGeachie AB, Chau N, Daniel JA, Gorgani NN, Robinson PJ, McCluskey A. Iminochromene inhibitors of dynamins I and II GTPase activity and endocytosis. J Med Chem. 2010; 53: 4094-102. doi: 10.1021/jm100119c.

115. Meng J, Wang J. Role of SNARE proteins in tumourigenesis and their potential as targets for novel anti-cancer therapeutics. Biochim Biophys Acta. 2015; 1856: 1-12. doi: 10.1016/j.bbcan.2015.04.002. 